Canadian

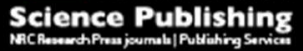

Botany

Botanique

\title{
A quantitative analysis of seed dormancy and germination in the winter annual weed Sinapis arvensis (Brassicaceae)
}

\begin{tabular}{|r|l|}
\hline Journal: & Botany \\
\hline Manuscript ID & cjb-2015-0166.R2 \\
\hline Danuscript Type: & Article \\
\hline Complete List of Authors: & $\begin{array}{l}\text { Soltani, Elias; University of Tehran, Agronomy and Plant Breeding Sciences } \\
\text { Baskin, Carol; University of Kentucky, } \\
\text { Baskin, Jerry; University of Kentucky, } \\
\text { Soltani, Afshin; Gorgan University of Agricultural Sciences and Natural } \\
\text { Resources, } \\
\text { Galeshi, Serolla; Gorgan University , Department of Agronomy, } \\
\text { Ghaderi-far, Farshid; Gorgan University of Agricultural Sciences and } \\
\text { Natural Resources, } \\
\text { Zeinali, Ebrahim; Gorgan University of Agricultural Sciences and Natural } \\
\text { Resources, }\end{array}$ \\
\hline Keyword: & $\begin{array}{l}\text { hydrothermal time, seed burial depth, dormancy-nondormancy cycle, } \\
\text { physiological dormancy }\end{array}$ \\
\hline & \\
\hline
\end{tabular}

SCHOLARONE ${ }^{\text {w }}$

Manuscripts 


\title{
A quantitative analysis of seed dormancy and germination in the winter annual weed Sinapis arvensis (Brassicaceae)
}

\author{
Elias Soltani* ${ }^{* 1}$, Carol C. Baskin ${ }^{2,3}$, Jerry M. Baskin ${ }^{2}$, Afshin Soltani ${ }^{4}$, Serolla Galeshi ${ }^{4}$, \\ Farshid Ghaderi-far ${ }^{4}$ and Ebrahim Zeinali ${ }^{4}$ \\ ${ }^{1}$ Department of Agronomy and Plant Breeding Sciences, Abourahian Campus, \\ University of Tehran, Tehran, Iran, ${ }^{2}$ Department of Biology, University of Kentucky, \\ Lexington, KY 40506, USA, ${ }^{3}$ Department of Plant and Soil Sciences, University of \\ Kentucky, Lexington, KY 40546, USA, ${ }^{4}$ Department of Agronomy, Gorgan \\ University of Agricultural Sciences and Natural Resources, Gorgan 49138-15739, \\ Iran
}

*Correspondence

Email: elias.soltani@ut.ac.ir 


\begin{abstract}
The aims of this study were to determine the effects of burial on germination and longevity and of water stress and temperature on germination and dormancy induction of the weed Sinapis arvensis. During exposure to the high temperatures of summer seeds buried in the field became nondormant, but low water potential and supraoptimal temperatures (constant not alternating) induced them into secondary dormancy. The threshold temperature for dormancy induction (TTDI) was about 19 ${ }^{\circ} \mathrm{C}$ when water was not limiting germination, and it decreased with a slope of $10^{\circ} \mathrm{C}$ per $\mathrm{MPa}$ as water potential decreased. Seeds had minimum dormancy (Dmin) when $\mathrm{T}<$ TTDI, and Dmin decreased $81.5 \%$ per MPa increase in water potential. Dormancy induction increased linearly with a slope of $13.23 \%$ for each additional centimetre of burial depth from 1 to $5.19 \mathrm{~cm}$. Dormancy was induced to its highest level (96\%) in seeds buried at a depth of $\geq 5.19 \mathrm{~cm}$; the remaining seeds were dead or were presumed to be dead Sinapis arvensis can form a persistent soil seed bank, and either water stress or conditions associated with increased burial depth can promote induction of secondary dormancy in the seeds.
\end{abstract}

Keywords: dormancy-nondormancy cycle; hydrothermal time; physiological dormancy; seed burial depth 


\section{Introduction}

Seeds of many weed species can persist for years in the soil seed bank, which begins at seed dispersal and ends with germination or death of the seed (Walck et al. 2005). Weed seeds have different fates after becoming part of the soil seed bank, and they can be viable or nonviable. Viable seeds are dormant (different degrees of dormancy) or nondormant. Nondormant seeds can germinate, or they may not germinate due to environmental factors such as lack of water or light. Living seeds eventually lose viability if they do not germinate during burial, or they may germinate in situ and the seedlings die without being able to emerge above the soil surface (Baskin and Baskin 2014). However, in many species seeds are dormant, and thus they will not germinate until dormancy is broken and conditions are favourable for germination. Buried seeds can cycle between dormancy and nondormancy in response to seasonal temperature changes (Baskin and Baskin 2014). After seeds become nondormant, seedling emergence from the soil depends on burial depth, which can influence weed seedling emergence by affecting the availability of soil moisture, $\mathrm{O}_{2}$ and light (Benvenuti 2007). Osmotic stress, hypoxia and other factors such as high or low temperatures may result in development of secondary seed dormancy (Gulden et al. 2004; Baskin and Baskin 2014). However, Gardarin et al. (2010) reported that germination of seeds of nine northwestern European agricultural weeds decreased with depth of seed burial, even if moisture, $\mathrm{O}_{2}$ and light did not change.

An important aspect of improving weed control practices is learning how to best manipulate seed dormancy, which controls weed seedling emergence in arable soil (Soltani et al. 2013). The most accurate way to determine the viability and germination ability of seeds in the soil is to bury them, wait for various periods of 
time, exhume samples and check for viability and germinability (Baskin and Baskin, 1985; 2006). This method allows one to determine if seeds exhibit dormancy/nondormancy cycling (Baskin et al. 2003; Masin et al. 2006).

Dormancy and germination of seeds are mainly affected by temperature and water potential (Batlla and Benech-Arnold 2004; Alvarado and Bradford 2005). The relationship between speed of germination and temperature can be described with mathematical functions (Soltani et al. 2006). The advantage of these functions is that they include parameters such as cardinal temperatures and maximum rates of germination or emergence that are meaningful from a biological point of view (Soltani et al. 2013). Thermal time (TT) and hydrotime (HT) models also have been used to describe the effect of temperature and water potential on seed germination and dormancy (Bradford 2002). Gummerson (1986) developed the hydrothermal time model by combining thermal time and hydrotime models, and it was extended by Bradford (1990, 1997, 2002). This model has wide application in studies of seed dormancy and germination (Meyer et al. 2000; Batlla and Benech-Arnold 2004; Alvarado and Bradford 2005; Meyer and Allen 2009). There are few studies on the hydrothermal germination of winter annuals (Meyer et akl., 2000; Meyer and Allen, 2009; Mesgaran et al., 2013), perhaps because the winter annual life cycle generally is not limited by soil moisture. However in warm and frequently dry environments, e.g. a Mediterranean climate, hydrothermal conditions could have a crucial role in the germination dynamics of winter annuals.

Using seeds of the facultative winter annual Sinapis arvensis, the aims of this study were to investigate the effects of (1) burial on germination and longevity, and (2) water stress and temperature on germination and dormancy induction. Specifically, we addressed the following questions. (1) What is the dormancy state 
and longevity of buried seeds over time? (2) What controls the timing of germination of buried seeds? (3) What are the effects of temperature and water potential on dormancy and germination? (4) What is the effect of burial depth on seedling emergence and dormancy?

\section{Materials and Methods}

Effect of burial on germination and viability of seeds in the soil - experiment 1

Sinapsis arvensis seeds were collected from oilseed rape (Brassica napus) fields around Gorgan, Iran $\left(36^{\circ} 51^{\prime} \mathrm{N}, 54^{\circ} 16^{\prime} \mathrm{E}\right.$ and $13 \mathrm{~m}$ asl; Mediterranean climate), during May 2009.A germination test of fresh seeds was conducted in the dark at $20{ }^{\circ} \mathrm{C}$, based on information for other species of Sinapis reported by the International Seed Testing Association (2009), and 100\% of the seeds were viable and 98\% dormant. Seeds were kept in the laboratory $\left(20 \pm 5{ }^{\circ} \mathrm{C}, 40 \pm 10 \% \mathrm{RH}\right.$, dark) until the beginning the experiment on 23 September 2009, and at this time another germination test was conducted at $20{ }^{\circ} \mathrm{C}$ in dark and in light. On this date, some of the seeds were buried in soil at the Gorgan University of Agriculture Science and Natural Resources

(GUASNR) Research Farm, and the other seeds were kept in dry storage in the laboratory. For burial, 1000 S. arvensis seeds and $10 \mathrm{~g}$ of soil (dried silty clay loam) were placed in each of $544 \times 8 \mathrm{~cm}$ nylon bags with a pore size of $10 \mu \mathrm{m}$. Each nylon bag was placed in a closed-top nylon basket to protect the seeds from predation, and the nylon baskets were buried at a soil depth of $30 \mathrm{~cm}$. Farmers usually moldboard plough to a depth of $30 \mathrm{~cm}$ in autumn in the conventional cropping system in Gorgan, resulting in some seeds possibly being buried at this depth.

After burial, three bags (replicates) of seeds were exhumed monthly for the duration of the experiment. The exhumed samples (containing soil and seeds) were placed on a 
mesh screen (holes $1 \times 2 \mathrm{~mm}$ ) and washed with tap water in room light. The isolated S. arvensis seeds were tested for viability by pinching 100 of them with fine-tipped forceps (crush test). The distinction between viable and nonviable seeds was based on seed firmness (firm vs. soft); soft seeds were considered to be dead and firm seeds viable (Borza et al., 2007; Taab and Andersson 2009). Decrease in seed viability was explained by a linear regression over time. Before regression analysis, data were transformed to a logarithmic scale. The regression model was back transformed to calculate the rates of seed loss.

Within $24 \mathrm{~h}$ after exhumation, viable seeds were used in germination tests conducted in dark and in light at $20{ }^{\circ} \mathrm{C}$. Seeds stored in the lab also were tested for germination under the same conditions. For seeds stored in the lab and for those that were exhumed from burial, there were three replications of 50 seeds for each test condition. Seeds were placed on moist filter paper (Whatman No. 40) moistened with $10 \mathrm{ml}$ of distilled water in 15-cm-diameter Petri dishes. Dark conditions were obtained by wrapping two layers of aluminum foil around each Petri dish. After 14 days, the germinated seeds were counted, and all remaining seeds were evaluated for dormancy and viability. For each month, nongerminated seeds were pinched with fine-tipped forceps (crush test) as described above. Germination percentage was based on number of viable seeds.

Minimum and maximum air temperatures during the experiment were obtained from a weather station with long-term reliable historical daily data in Gorgan. Soil temperatures were estimated using a regression model developed by Soltani et al. (2006) for Gorgan as follows:

$$
y=1.046 x-0.1616
$$

where $\mathrm{x}$ and $\mathrm{y}$ are air and soil temperatures, respectively. 
Effect of water stress and temperature on germination and dormancy induction of nondormant seeds-experiment 2

Seeds were prepared as described in experiment 1 . They were maintained in dry storage in the laboratory (as in experiment 1$)$ until the beginning of experiment 2 (25 Oct 2009). Four replicates of 50 nondormant seeds, i.e. dormancy released by treating seeds with 2000 ppm GA3 (Edwards, 1969), were incubated in darkness at seven constant temperatures from 5 to $35^{\circ} \mathrm{C}$ at $5{ }^{\circ} \mathrm{C}$ intervals and five water potentials, 0 , $0.2,-0.4,-0.6$ and $-0.8 \mathrm{MPa}$ at each temperature. Water potentials were maintained with solutions of polyethylene glycol 8000 (Michel 1983). Before seed placement, the filter paper was soaked for $24 \mathrm{~h}$ in Petri dishes containing an osmotic solution for the desired water potential. Seeds were monitored for germination twice a day (for 1 month), and they were considered to be germinated when the radicle was $\geq 2 \mathrm{~mm}$ long. After the germination test, the percentage of dormant viable seeds was determined by the crush test as explained in experiment 1 .

Estimates of the time taken for cumulative germination to reach $50 \%$ of the maximum number of viable seeds in each replicate (D50) were interpolated from the germination progress curve versus time (Soltani et al., 2001). Visual basic editor of Excel was used to obtain D50 from cumulative germination versus time. Germination speed $\left(\mathrm{R} 50 \mathrm{~h}^{-1}\right)$ was calculated according to Soltani et al. (2001):

$$
R 50=1 / D 50
$$

To quantify the response of germination speed to temperature and to determine cardinal temperatures for germination, the following model was used for each water potential: 


$$
R 50=f(T) R_{\max }
$$

where $f(T)$ is a temperature $\left({ }^{\circ} \mathrm{C}\right)$ function and $R_{\max }$ the maximum rate of germination at the optimal temperature. Thus, $1 / R_{\max }$ indicates the minimum number of hours required for germination at the optimal temperature. The Dent-like function $(f(T))$, one of many functions that can be used to describe germination response to temperature, were used (Soltani et al. 2006):

$$
\begin{gathered}
f(T)=\frac{T-T_{b}}{T_{o 1}-T_{b}} \quad \text { if } \quad T_{b}<T<T_{o 1} \\
f(T)=\frac{T_{c}-T}{T_{c}-T_{o 2}} \quad \text { if } \quad T_{o 2}<T<T_{c} \\
f(T)=1 \quad \text { if } \quad T_{o 1}<T<T_{o 2} \\
f(T)=0 \quad \text { if } \quad T \leq T_{b} \text { or } T \geq T_{c}
\end{gathered}
$$

where $T$ is the temperature $\left({ }^{\circ} \mathrm{C}\right), T_{b}$ base temperature, $T_{o l}$ lower optimum temperature, $\mathrm{T}_{\mathrm{o} 2}$ upper optimum temperature and $T_{c}$ ceiling temperature. The parameters were estimated by the least squares method using the non-linear (NLIN) regression $\left(R_{50}\right.$ as $y$ and $T$ as $\left.x\right)$ procedure in SAS software.

A thermal time $\left(\mathrm{TT}^{\circ} \mathrm{C}\right.$ day) model was fitted using the following equation at sub- (5) and supra- (6) optimal temperatures (Bradford, 2002):

$$
\begin{aligned}
& T T_{\text {sub }}=\left(T-T_{b}\right) t_{g} \\
& T T_{\text {supra }}=\left(T_{c}-T\right) t_{g}
\end{aligned}
$$

where $\mathrm{T}$ is the actual temperature, $T_{b}$ base temperature, $T_{c}$ ceiling temperature for germination and $\mathrm{tg}$ time from addition of water to germination $(\mathrm{g})$.

Quantification of seed germination was conducted in relation to water potential using the hydrotime model for each temperature (Gummerson 1986; Bradford 1990; Dahal and Bradford 1994): 


$$
\theta_{H}=\left(\varphi-\varphi_{b}(g)\right) t_{g}
$$

where $\theta_{\mathrm{H}}$ is the hydrotime constant (MPa-hours), $\psi$ actual seed water potential (MPa), $\psi_{\mathrm{b}}(g)$ base water potential $(\mathrm{MPa})$ defined for a specific germination fraction $(g)$ and $t_{g}$ time (hours) to radicle emergence of fraction $g(\%)$ of the seed population.

Assuming that the variation in $\psi_{\mathrm{b}}$ within a seed lot follows a normal distribution, hydrotime parameters were estimated by repeated probit analysis (equation 8) by varying $\theta_{\mathrm{H}}$ until the best fit was reached for whole seed lots (Dahal and Bradford 1994):

$$
\operatorname{probit}(g)=\left[\psi-\left(\theta_{\mathrm{H}} / t_{g}\right)-\psi_{\mathrm{b}}(50)\right] / \sigma_{\psi \mathrm{b}}
$$

where $\psi_{\mathrm{b}}(50)$ is the median $\psi_{\mathrm{b}}$ and $\sigma_{\psi \mathrm{b}}$ the standard deviation of $\psi_{\mathrm{b}}$ among seeds within the temperatures.

Dormancy induction was quantified with segmented functions on the response to temperature separately for each water potential as follows:

$$
\begin{gathered}
D=D \min , \quad \text { if } T>T T D I \\
D=D \min +b \times(T-T T D I), \text { if } T \geq T T D I
\end{gathered}
$$

where $\mathrm{T}$ and $\mathrm{D}$ are temperature $\left({ }^{\circ} \mathrm{C}\right)$ and percentage of dormant seeds, respectively, and Dmin, TTDI and $b$ are the model parameters for minimum dormancy for each water potential, threshold temperature for dormancy induction and the slope of the increasing dormancy level, respectively. The parameters were estimated by the least squares method using the non-linear (NLIN) regression ( $\mathrm{D}$ as $\mathrm{y}$ and $\mathrm{T}$ as $\mathrm{x}$ ) procedure in SAS.

Effects of burial depth on seedling emergence and dormancy - experiment 3 
The effect of burial depth on seedling emergence was studied in a roofless enclosure at GUASNR so that the buried seeds could be exposed to near-outdoor weather conditions. As described for experiments 1 and 2, 50 nondormant seeds (dormancy released by $2000 \mathrm{ppm} \mathrm{GA}_{3}$ ) were sown at depths of $1,2,3,4,5,6,8,10,12,15,20$ and $30 \mathrm{~cm}$ in plastic pots $(15 \mathrm{~cm}$ diameter and $40 \mathrm{~cm}$ deep $)$ filled with a silty clay loam soil ( $28 \%$ clay, $62 \%$ silt, $10 \%$ sand). The soil was excavated from a depth of $>$ $0.5 \mathrm{~m}$ from farmland that not been plowed for at least for 50 years to avoid the presence of seeds of $S$. arvensis, which would invalidate the experimental data on seedling emergence. The pots were filled gravimetrically with the soil and packed to uniform strength to avoid differential resistance to seedling emergence. Holes in the bottom of the pots allowed drainage of excess water.

The experiment was a completely randomised design with four replicates for each seeding depth. It began on 1 Jan 2010, and the mean temperature during the experiment was $10.61 \pm 6.53{ }^{\circ} \mathrm{C}$ (mean minimum air temperature $5.98 \pm 3.24$ and mean maximum air temperature $15.24 \pm 4.37$ ). Each pot was irrigated at 2- or 3-day intervals with $100 \mathrm{ml}$ of water and observed daily for seedling emergence for 45 days; no seedling emerged after about 20 days. Emerged seedlings were counted and removed daily. After 45 days, the soil in the pots was examined for intact seeds by sieving it. Viable seeds were separated from dead seeds by the crush test as explained in experiment 1. Estimates of the time taken for cumulative emergence to reach $50 \%$ of the maximum number of emerged seedlings (D50) for each replicate were interpolated from the emergence progress curve as described in equation (2).

The relationship between seedling emergence percentage and burial depth was described using an exponential model:

$$
y=y_{\max } \quad \text { if } x<x_{o}
$$




$$
y=y_{\max }\left(-b\left(x_{o}-x\right)\right) \quad \text { if } x \geq x_{o}
$$

where $\mathrm{x}$ and $\mathrm{y}$ are burial depth and seedling emergence rate, respectively, and $\mathrm{y}_{\max }, \mathrm{b}$ and $\mathrm{x}_{0}$ are model parameters showing the maximum rate of seedling emergence, slope and the turning point in a non-linear regression, respectively. The same model was used to describe dormancy induction as affected by the depth of burial:

$$
\begin{array}{ll}
y=y_{\max }\left(b \times\left(x-x_{o}\right)\right) & \text { if } x<x_{o} \\
y=y_{\max } & \text { if } x \geq x_{o}
\end{array}
$$

where $\mathrm{x}$ and $\mathrm{y}$ are burial depth and percentage of dormant seeds, respectively, and $\mathrm{y}_{\max }, \mathrm{b}$ and $\mathrm{x}_{0}$ are model parameters showing the maximum dormancy induction, slope and the turning point in a non-linear regression, respectively. The parameters were estimated by the least squares method using the non-linear (NLIN) regression procedure in SAS.

\section{Results}

Effect of burial on germination and viability of seeds in the soil - experiment 1

Almost $100 \%$ of the seeds buried on 23 September 2009 were viable. Seed viability decreased at a constant rate of $1.9 \%$ per 100 days [model based on back transformed data during the 570 days of the experiment (data not shown)]. Viability of seeds stored under laboratory conditions did not decrease during the experiment. Lab-stored seeds germinated to $0.7-4.8 \%$ in dark and 0.4-7.6 \% in light, and there were no significant differences over time (Fig 1).

Germination at the beginning of experiment was 2.7 and $5.4 \%$ in dark and light, respectively (Fig. 1a). After 1 month of burial (23 October 2009), germination percentage was low, and it increased for seeds tested on 23 November and 23 
December 2009, with another decrease until August 2010. There was no significant difference in germination for November 2009-exhumed seeds incubated in dark and light, but December 2009-exhumed seeds germinated to a significantly higher percentage in light than in dark. Maximum germination of buried seeds was 51 and $68 \%$ on 23 September 2010 in dark and light, respectively. Germination percentage was maximum from 23 August 2010 (last month of summer) to 23 February 2011 (last month of winter), with a decrease in November 2010.

Effect of water stress and temperature on germination and dormancy induction of nondormant seeds-experiment 2

Estimates of cardinal temperatures were 0.30 to $1.94{ }^{\circ} \mathrm{C}$ for $\mathrm{T}_{\mathrm{b}}, 17.2$ to $21.4{ }^{\circ} \mathrm{C}$ for $\mathrm{T}_{\mathrm{o} 1}, 21.7$ to $25.0{ }^{\circ} \mathrm{C}$ for $\mathrm{T}_{\mathrm{o} 2}$ and 30.0 to $36.6{ }^{\circ} \mathrm{C}$ for $\mathrm{T}_{\mathrm{c}}$, and estimates of $R_{\max }$ were 0.0102 to $0.0160 \mathrm{~h}^{-1}$ (Table 1 ; Fig 2). The median thermal time to germination $\left(\mathrm{TT}_{(50)}\right)$ increased from $50.54{ }^{\circ} \mathrm{C} \mathrm{d}(0 \mathrm{MPa})$ to $79.3{ }^{\circ} \mathrm{C} \mathrm{d}(\psi=-0.6 \mathrm{MPa})$ at low $\psi$ and suboptimal temperatures (Table 1). Under supra-optimal temperatures, $\mathrm{TT}_{(50)}$ ranged from 19.7 to $41.1{ }^{\circ} \mathrm{C}$ d. The $\mathrm{R}^{2}$ values indicate a good fit of the thermal time model under both sub- and supra-optimal temperatures. The predicted germination time courses at the various water potentials $(\psi)$ and temperatures generally fitted well with the observed germination data, with $\mathrm{R}^{2}$ values of 0.92 to 0.98 (Fig 3; Table 2). The estimated values of $\psi_{\mathrm{b}(50)}, \sigma_{\psi \mathrm{b}}$ and $\mathrm{HT}_{(50)}$ differed at different germination temperatures (Table 2). The highest $\mathrm{HT}_{(50)}$ and lowest $\psi_{\mathrm{b}(50)}$ were observed at $5^{\circ} \mathrm{C}$ and $15^{\circ} \mathrm{C}$, respectively.

The percentage of dormant seeds increased significantly with increasing temperature or decreasing water potential (Fig 4). $\mathrm{R}^{2}$ values were $0.96,0.96,0.95$ and 
0.99 for $-0.6,-0.4,-0.2$ and $0 \mathrm{MPa}$, respectively. At $0 \mathrm{MPa}, \mathrm{GA}_{3}$ overcame seed dormancy, but $15.8 \%$ of seeds (Dmin) were dormant even at the optimum temperature and water potential. There was a linear relationship between Dmin and water potential, and Dmin was reduced by $81.5 \%$ with each increase in water potential (Fig 5a). The threshold temperature for dormancy induction (TTDI) was $18.9{ }^{\circ} \mathrm{C}$ in $0 \mathrm{MPa}$, and higher temperatures increased dormancy induction by a slope of $5.3 \%$ (Fig 4). For water stressed seeds, TTDI decreased significantly with a fixed slope (Fig 5b). TTDIs were 18.9, 20, 15.6 and $13.7^{\circ} \mathrm{C}$ at $0,-0.2,-0.4$ and $-0.6 \mathrm{MPa}$, respectively. Minimum dormancy (Dmin) was 40.1, 54.2 and $65.5 \%$ at $-0.2,-0.4$ and $-0.6 \mathrm{MPa}$, respectively (Fig 4).

Effects of burial depth on seedling emergence and dormancy - experiment 3

The dormancy level depended on location of seeds in the soil profile, and it ranged from $28.5 \%$ (at $1 \mathrm{~cm}$ depth) to $>90 \%$ ( $\geq 6 \mathrm{~cm}$ ) (Fig 6). The percentage of dead seeds did not change with increasing burial depth, and it ranged from 1.9 to $4.3 \%$ (Fig 6). Maximum seedling emergence (68.4\%) was at a burial depth of $1 \mathrm{~cm}$, and seedling emergence percentage decreased from $1 \mathrm{~cm}$ to $8 \mathrm{~cm}$ soil depths (Fig 6). No seedlings emerged from seeds buried at a depth of $8 \mathrm{~cm}$, and seedling emergence for seeds buried at $6 \mathrm{~cm}$ was only $5 \%$ (Fig 6). Seedling emergence percentage was described well by exponential regression (Fig 7a). $\mathrm{R}^{2}$ and RMSE values for the model were 0.97 and 4.22, respectively. Seedling emergence rate was satisfactorily described by a segmented model $\left(\mathrm{R}^{2}=0.99\right)($ Figure $7 \mathrm{~b})$. Thus, there was no change in rate of seedling emergence (around $0.08 \mathrm{day}^{-1}$ ) from a burial depth of $1 \mathrm{~cm}$ to $3.84 \mathrm{~cm}$. However, burial in deeper layers of soil reduced seedling emergence rate by a fixed 
slope of 0.02 (Fig. 7b). Percentage of dormant seeds increased with burial depth, and this response was described by a segmented function (Fig 8). Induction of dormancy increased linearly from 1 to $5.19 \mathrm{~cm}$ with a slope of $13.2 \%$. The non-linear regression model showed that dormancy induction was about $96 \%$ at burial depths of 5.19 to 30 $\mathrm{cm}$ (Fig 8).

\section{Discussion}

Knowing the rate at which seeds buried in the soil lose viability can be helpful in the management of weeds in arable fields (Masin et al. 2006). Loss of viability in a cohort of S. avensis seeds in the soil exhibited a Deevey Type II survivorship curve, i.e. a constant probability of death (Roberts and Dawkins 1967; Roberts and Feast 1973ab; Murdoch 2006). However, after longer periods of time the curve may be of another type. Seed viability decreased at a constant rate of $1.9 \%$ per 100 days $(6.9 \%$ per year) during 570 days (experiment 1). Edwards (1980) reported that annual emergence of S. arvensis seedlings in field plots in the United Kingdom was c. $2.5 \%$ of the seed population and estimated that the annual death of seeds in the soil was $\mathrm{c}$. 17.9\%. At Wellesbourne in the United Kingdom, Roberts and Boddrell (1983) documented seedling emergence from $S$. arvensis seeds buried in nondisturbed soil in 1965, 1966 and 1967 for five consecutive years for each burial date, after which 9.1, 6.5 and $2.6 \%$, respectively, of the buried seeds were viable. Donald (1993) used several regression models to describe $S$. arvensis seed survival during 4 years and found that it decreased from $100 \%$ to about 60 and $90 \%$ after 1 year of burial in two different trials. 
Seed longevity is influenced by several factors in the soil seed bank, and it may increase (Walker et al., 2010), decrease (Steckel et al., 2007) or not change (Egley and Chandler, 1983) with soil depth. Soil disturbance increases soil aeration and exposes seeds to light, thereby improving conditions for germination and reducing seed longevity (Cardina et al. 1998). Soil texture and structure, kind of plow, depth of disturbance, timing and amount of precipitation and irrigation, temperature and gas $\left(\mathrm{CO}_{2} / \mathrm{O}_{2}\right)$ exchange potential of soil affect seed mortality, germination and dormancy in the soil seed bank (Baskin and Baskin 2014). In addition to the effects of environmental factors, including predation, natural ageing of seeds determines their maximum longevity in soil seed banks (Davis et al. 2008). Longevity of seeds in the soil is influenced by, moisture content, chemical composition and vigour of seeds, and it varies among species (Baskin and Baskin 2014). Garbutt and Witcombe (1986) reported that seeds of S. arvensis produce two "cohorts" of seedlings each year, one in spring and the other in autumn. Plants from seeds germinating in spring would behave as summer annuals, and those from seeds germinating in autumn would behave as winter annuals. Chepil (1946) and Roberts and Boddrell (1983) found that most seedlings of S. arvensis emerged in April-July in Canada and March-April in the United Kingdom, respectively, with sporadic emergence at other times during the growing season. Thus, most plants in Canada and England would be summer annuals. However, in Iran most plants are derived from seeds that germinate in autumn, and winter and consequently plants behave as winter annuals. In the second year of experiment 1 in our study, maximum germination was observed during the period of 23 August 2010 (last month of summer) to 23 February 2011 (last month of winter). Although there was a decline in germination of exhumed seeds in November 2011, there was no abrupt change in the temperature between October and December (Fig. 
1b) that might help account for induction of secondary dormancy; soil moisture data were not collected, so possible effects of water stress are unknown.

Overall, our results are similar to those reported by Chepil (1946) and Roberts and Boddrell (1983) in that there was only one major period of germination during the study. However, unlike these two studies in which seeds were exposed to natural seasonal temperature changes, we incubated seeds at $20^{\circ} \mathrm{C}$, which would approximate spring temperatures in Canada and the United Kingdom. Consequently, in our study seeds were capable of germinating for a longer period of time (late August to late February) than they were in the studies by by Chepil (1946) and Roberts and Boddrell (1983). Our seeds were always incubated at $20^{\circ} \mathrm{C}$, while those in the other two studies were germinating at natural field temperatures. Thus, it seems reasonably that as temperatures (and possibly water stress) increased in Canada (Chepil, 1946) and the United Kingdom (Roberts and Boddrell, 1983) with the beginning of summer there would be a decline in germination.

The increase in germination percentage between the time seeds were buried in September and exhumed in November indicates that some dormancy break occurred during this time (Fig. 1a). Roberts and Boddrell (1983) reported that some seeds of $S$. arvensis germinated immediately after they were sown in autumn. They also found some variation in the degree of dormancy in seeds collected in different years and thus different germination percentages of autumn-sown seeds. Although exhumed seeds germinated to 48 and $22 \%$ at $20^{\circ} \mathrm{C}$ in our study in November and December 2009, respectively, they did not reach $20 \%$ germination again until July 2010. During the period January to June-July 2010, dormancy break occurred in the buried seeds, and from August 2010 to February 2011 germination of exhumed seeds at $20^{\circ} \mathrm{C}$ ranged from 35 to $70 \%$. The lab-stored seeds did not afterripen and maximum 
germination was c. $10 \%$. Thus, the summer environmental conditions (probably the long period at high summer temperatures) promoted dormancy-break, but those in the lab did not.

Between February and April 2011, buried seeds of S. arvensis lost the ability to germinate at $20^{\circ} \mathrm{C}$. According to the literature review conducted by Gardarin and Colbach (2015), dormancy induction occurs in buried seeds of S. arvensis between March and June. However, a limitation of experiment 1 in our study is that exhumed seeds were tested for germination only at $20^{\circ} \mathrm{C}$. Thus, we cannot determine if the low germination percentage in April 2011 represents an induction into dormancy (loss of ability to germinate over the full range of temperatures at which nondormant seeds can germinate) or into conditional dormancy (loss of ability to germinate at some portion of the range of temperatures at which nondormant seeds can germinate). The loss of ability of buried S. arvensis seeds to germinate at $20^{\circ} \mathrm{C}$ as temperatures increase in spring is similar to the responses of buried seeds of the weedy winter annual Capsella bursa-pastoris. Whereas buried seeds of winter annuals typically enter secondary dormancy in autumn and early winter (as temperatures decrease), those of C. bursa-pastoris do not enter secondary conditional dormancy until spring (as temperatures increase) (Baskin and Baskin 1989). Buried seeds of C. bursapastoris exhibit an annual nondormancy (ND)/conditional dormancy (CD) cycle, and based on the similarity of germination response of S. arvensis and C. bursa-pastoris seeds, it is assumed that buried seeds of $S$. arvenesis also have an annual ND/CD cycle.

Much is known about the dormancy breaking and germination requirements of seeds of winter annuals, especially with regard to responses to temperature (Baskin and Baskin 2014). However, there are only a few reports of using hydrothermal time 
models to investigate seed dormancy and germination in winter annual weeds:

Bromus tectorum (Bauer et al. 1998, Bair et al. 2006; Meyer et al., 2000; Meyer and Allen, 2009), Hordeum spontaneum, Phalaris minor, Raphanus raphanistrum

(Mesgaran et al. 2013) and volunteer oil seed rape (Soltani et al. 2013). Our study quantified the germination responses of $S$. arvensis seeds to temperature and water potential by hydrotime and thermal time models for the first time. The lowest $\psi_{\mathrm{b}}(50)$ was observed at $15^{\circ} \mathrm{C}$ (Table 2), and dormancy induction also was low at $15^{\circ} \mathrm{C}$ (Fig 5). The mean percentage of dormant seeds was 49.1, 43.1, 43.1, 49.7, 67.3, 90.7 and 99.7 at $5,10,15,20,25,30$ and $35^{\circ} \mathrm{C}$, respectively, across the range of water potentials. Thus, low soil water potential and supra-optimal temperatures that occur with the beginning of summer can induce seeds of S. arvensis into secondary dormancy. Seeds that germinate at lower $\psi_{\mathrm{b}}(50)$ have lower degrees of dormancy, and increasing temperature leads to increase in $\psi_{\mathrm{b}}(50)$ (Meyer et al. 2000; Meyer and Allen 2009). The threshold temperature for dormancy induction (TTDI) in S. arvensis was about $19{ }^{\circ} \mathrm{C}$ when water was not limiting germination, and TTDI decreased as water potential decreased, with a slope of $10{ }^{\circ} \mathrm{C}$ per MPa (Fig 5, 6b).

Dormancy in S. arvensis seeds also can be described with Dmin. This parameter shows the minimum depth (intensity) of dormancy when $\mathrm{T}<\mathrm{TTDI}$ for each water potential and therefore the portion of dormancy induction due to water potential. Luzuriaga et al. (2006) found that small plants of $S$. arvensis mainly produced black seeds and large plants produced red seeds, Further, black seeds had stronger dormancy than red seeds. We used a mixed seed lot, and this may help to explain why a portion of the seeds remained dormant (Dmin) even after treatment with $\mathrm{GA}_{3}$ and incubation at optimum water potential and temperature. Dmin decreased $81.5 \%$ with each increase in water potential (Fig 5a). It seems, then, that Dmin also can be used to 
show depth (intensity) of nondeep PD at the non-limiting water potential. Dormancy induction did not change significantly between low and high temperatures (when $\mathrm{T}<$ TTDI), but there was a slightly greater increase in dormancy induction at $5{ }^{\circ} \mathrm{C}$ than at 10 or $15{ }^{\circ} \mathrm{C}$, especially at lower water potentials (Fig 4). It is well known that low temperatures such as $5^{\circ} \mathrm{C}$ can induce seeds of winter annuals into secondary dormancy (Baskin and Baskin, 2014). Thus, induction of dormancy in buried seeds of S. arvensis between February and April 2011 may be related more to increase in water stress than to increase in temperature.

Seeds of $S$. arvensis are very sensitive to water stress, and a decrease in water potential to $-0.6 \mathrm{MPa}$ can induce secondary dormancy (at least $65 \%$ at $\mathrm{T}<\mathrm{TTDI}$ ). This response to water stress has the potential to be of use in management of this winter annual weed because crop species such as oil seed rape (Soltani et al. 2013) and sugarbeet (Farzane \& Soltani, 2011) can germinate at $\psi_{\mathrm{b}}(50)$ lower than -0.6 MPa. Thus, we suggest that water stress could be used to induce seeds of $S$. arvensis into secondary dormancy, but the stress would not prevent germination of the crop species. However, although $S$. arvensis would not be competiting with crop plants, its seeds would remain in the soil seed bank and be a problem in future years. There are other reports of dormancy induction by water stress in weedy species such as Chenopodium bonus-henricus L. (Khan and Karssen 1980), Rumex crispus (Samimy and Khan 1983) and volunteer oil seed rape (Momoh et al. 2002; Gulden et al. 2004). Gulden et al. (2004) showed that a decrease in water potential increased the rate of dormancy induction in oil seed rape, and Momoh et al. (2002) found that osmotic stress was more effective than low oxygen concentration in inducing dormancy in seeds of this species. 
In experiment 3, the rate and percentage of seedling emergence of S. arvensis decreased with an increase in burial depth, and the percentage of seeds induced into dormancy increased. In general, failure of seedlings to emerge could result from (1) unfavourable conditions for germination, (2) induction of seed dormancy or (3) preemergence mortality (fatal germination). Dormancy induction in S. arvensis increased linearly with a slope of $13.23 \%$ with each additional centimetre of burial depth from 1 to $5.19 \mathrm{~cm}$, and it was highest $(96 \%)$ in seeds at depths $\geq 5.19 \mathrm{~cm}$ (Fig 8). The reason for increased dormancy with increased depth of seed burial was not determined. However, given that seeds were in pots in the same location in the greenhouse and that the soil was watered regularly, it does not seem likely that either temperature or water stress is related to the linear increase in dormancy induction with depth. The decrease in germination with an increase in depth of burial may be due to the re-induction of dormancy.

Re-induction of dormancy in buried seeds may be linked to interactions between seed metabolism and the soil gas environment, rather than the depletion of seed energy reserves (Benvenuti et al., 2001). Decreased metabolic activity of buried seeds, confirmed by a slower seedling emergence, would prevent the toxic fermentation metabolites from reaching the threshold that can block seed germination and re-induce dormancy (Holm, 1972). However, high soil moisture, soil compaction, high microbial activity and/or poor soil structure may decrease soil oxygen concentration or inhibit movement of gases within the soil, leading to accumulation ofvolatile fermentation products that inhibit germination (Chantre et al. 2009). Edwards (1969) found that a decrease in oxygen concentration, such as might be expected with an increase in soil depth, did not induce seeds of S. arvensis into dormancy per se. 
However, at oxygen levels below 0.1 atm the rate of production of germinationinhibiting substances increased with a decreased in oxygen supply.

In summary, freshly-matured seeds of $S$. arvensis were dormant when collected in May 2009 (spring) and did not after-ripening during 23 months of dry storage under ambient laboratory conditions. However, seeds buried in the soil in October 2009 germinated to high percentages when exhumed monthly from August 2010 to February 2011 and tested at $20^{\circ} \mathrm{C}$ but did not germinate when exhumed in April 2011. Our studies on germination responses of $S$. arvensis seeds to temperature and water potential using hydrotime and thermal time models reveal that low water potential is an importantfactor in inducing seeds into secondary dormancy, which helps to explain why dormancy induction in seeds of this weedy winter annual is delayed until spring when temperatures and thus water stress are increasing. We also found that an increase in burial depth increased the percentage of seeds induced into secondary dormancy. However, mean temperature and water content did not explain the relationship between depth of seed burial and dormancy induction. Thus, depth of burial per se also can promote induction of secondary dormancy and thereby potentially increase the size of the soil seed bank.

\section{References}

Alvardo, V., and Bradford, K.J. 2005. Hydrothermal time analysis of seed dormancy in true (botanical) potato seeds. Seed Sci. Res. 15(2): 77-88. doi: 10.1079/SSR2005198.

Bair, N.B., Meyer, S.E., and Allen, P.S. 2006 A hydrothermal after-ripening time model for seed dormancy loss in Bromus tectorum L. Seed Sci. Res. 16(1): 17-28. doi: 10.1079/SSR2005237. 
Baskin, C.C., and Baskin, J.M. 2006. The natural history of soil seed banks of arable land. Weed Sci. 54(3): 549-557. doi: 10.1614/WS-05-034R.1

Baskin, C.C., and Baskin, J.M. 2014. Seeds: ecology, biogeography, and evolution of dormancy and germination (2nd edition). Elsevier/Academic Press, San Diego, CA, USA.

Baskin, C.C., Baskin, J.M., and Chester, E.W. 2003. Ecological aspects of seed dormancy-break and germination in Heteranthera limosa (Pontederiaceae), a summer annual weed of rice fields. Weed Res. 43(3): 103-107. doi: $10.1046 / \mathrm{j} .1365-3180$.

Baskin, J.M., and Baskin, C.C. 1985. Does seed dormancy play a role in the germination ecology of Rumex crispus? Weed Sci. 33(3): 340-343.

Baskin, J.M., and Baskin, C.C. 1989. Germination responses of buried seeds of Capsella bursa-pastoris exposed to seasonal temperature changes. Weed Res. 29(3): 205-212. doi: 10.1111/j.1365-3180

Batlla, D., and Benech-Arnold, R.L. 2004. Seed dormancy loss assessed by changes in population hydrotime parameters: development of a predictive model. Seed Sci. Res. 14(3): 277-286. doi: 10.1079/SSR2004177.

Bauer, M.C., Meyer, S.E., and Allen, P.S. 1998 A simulation model to predict seed dormancy loss in the field for Bromus tectorum L. J. Exp. Bot. 49(324): 12351244. doi: $10.1093 / \mathrm{jxb} / 49.324 .1235$.

Benvenuti, S. 2007. Natural weed seed burial: effect of soil texture, rain and seed characteristics. Seed Sci. Res. 17(3): 211-219. 10.1017/S0960258507782752.

Benvenuti, S., Macchia, M., and Miele, S. 2001. Light, temperature and burial depth effects on Rumex obtusifolius seed germination and emergence. Weed Res. 41(2), 177-186. doi: 10.1046/j.1365-3180.2001.00230.x 
Borza, J.K., Westerman, P.R., and Liebman, M. 2007. Comparing estimates of seed viability in three foxtail (Setaria) species using the imbibed seed crush test with and without additional tetrazolium testing. Weed Technol. 21(2), 518-522. doi: 10.1614/WT-06-110.

Bradford, K.J. 1990. A water relation analysis of seed germination rates. Plant Physiol. 94(2): 840-849.

Bradford, K.J. 1997. The hydrotime concept in seed germination and dormancy. In: Basic and applied aspects of seed biology. Edited by R.H. Ellis, M. Black, A.J. Murdoch, and T.D. Hong. Kluwer Academic Publishers, Boston. pp. 349-360.

Bradford, K.J. 2002. Applications of hydrothermal time to quantifying and modeling seed germination and dormancy. Weed Sci. 50(2): 248-260. doi: 10.1614/00431745.

Cardina, J., Webster, T.M., and Herms, C.P. 1998. Long-term tillage and rotation effects on soil seedbank characteristics. Aspects Appl. Biol. 51: 213-220.

Chantre, G.R., Sabbatini, M.R., and Orioli, G.A. 2009. Effect of burial depth and soil water regime on the fate of Lithospermum arvense seeds in relation to burial time. Weed Res. 49(1), 81-89. DOI: 10.1111/j.1365-3180.2008.00671.x

Chepil, W.S. 1946. Germination of weed seeds: II. The influence of tillage treatments on germination. Scient. Agric. 26: 347-357.

Dahal, P., and Bradford, K.J. 1994. Hydrothermal time analysis of tomato seed germination at suboptimal temperature and reduced water potential. Seed Sci. Res. 4(2): 71-80. doi: 10.1017/S096025850000204X.

Davis, A.S., Schutte, B.J., Iannuzzi, J., and Renner, K.A. 2008. Chemical and physical defense of weed seeds in relation to soil seedbank persistence. Weed Sci. 56(5): 676-684. doi: 10.1614/WS-07-196.1. 
Donald, W.W. 1993. Models and sampling for studying weed seed survival with wild mustard (Sinapis arvensis) as a case study. Can. J. Plant Sci. 73(2): 637-645. doi: 10.4141/cjps93-085.

Edwards, M. 1969. Dormancy in seeds of charlock. IV. Interrelationships of growth, oxygen supply and concentration of inhibitor. J. Exp. Bot. 20(4): 876-894. doi: $10.1093 / \mathrm{j} x \mathrm{~b} / 20.4 .876 . ।$

Edwards, M. 1980. Aspects of the population ecology of Charlock. J. App. Eco. 17(1), 151-172.

Egley, G. H. and Chandler, J. M. 1983. Longevity of weed seeds after 5.5 years in the Stoneville 50-year buried-seed study. Weed Sci. 31, 264-270.

Farzane, S., and Soltani, E. (2011) Relationships between hydrotime parameters and seed vigor in sugar beet. Seed Sci. Biotech. 5(1): 7-10.

Garbutt, K., and Witcomb, E.T. Jr. 1986. The inheritance of seed dormancy in Sinapis arvensis L. Heredity 56(1): 25-31. doi:10.1038/hdy.1986.5.

Gardarin, A., and Colbach, N. 2015. How much of seed dormancy in weeds can be related to seed traits? Weed Res. 55(1): 14-25. doi: 10.1111/wre.12121.

Gardarin, A., Durr, C., and Colbach, N. 2010. Effects of seed depth and soil structure on the emergence of weeds with contrasting seed traits. Weed Res. 50(2): 91-101. doi: 10.1111/j.1365-3180.

Gulden, R.H., Thomas, A.G., and Shirtliffe, S.J. 2004. Secondary dormancy, temperature, and burial depth regulate seedbank dynamics in canola. Weed Sci. 52(3): 382-388. doi: 10.1614/WS-03-123R1.

Gummerson, R.J. 1986. The effect of constant temperature and osmotic potential on the germination of sugar beet. J. Exp. Bot. 37(6): 729-741. doi: 10.1093/jxb/37.6.729. 
Holm, R.H. 1972. Volatile metabolites controlling germination in buried weed seeds. Plant Physiol. 50(2):293-297.

ISTA (2009). International Rules for Seed Testing, International Seed Testing Association, Bassersdorf, Switzerland.

Khan, A.A., and Karssen, C.M. 1980. Induction of secondary dormancy in Chenopodium bonus-henricus L. seeds by osmotic and high temperature treatments and its prevention by light and growth regulators. Plant Physiol. 66: 175-181.

Luzuriaga, A.L., Escudero, A., and Perez-Garcia, F. 2006. Environmental maternal effects on seed morphology and germination in Sinapis arvensis (Cruciferae). Weed Res. 46(2): 163-174. doi: 10.1111/j.1365-3180.

Masin, R., Zuin, M.C., Otto, S., and Zanin, G. 2006. Seed longevity and dormancy of four summer annual grass weeds in turf. Weed Res. 46(5): 362-370. doi: $10.1111 / \mathrm{j} .1365-3180$.

Mesgaran, M.B., Mashhadi, H.R., Alizadeh, H., Hunt, J., Young, K.R., and Cousens, R.D. 2013. Importance of distribution function selection for hydrothermal time models of seed germination. Weed Res. 53(2): 89-101. doi: 10.1111/wre.12008.

Meyer, S.E. and Allen, P.S. 2009. Predicting seed dormancy loss and germination timing for Bromus tectorum in a semi-arid environment using hydrothermal time models. Seed Sci. Res. 19(4): 225-239. doi: 10.1017/S0960258509990122.

Meyer, S.E., Debaene-Gill, S.B. and Allen, P.S. 2000. Using hydrothermal time concepts to model seed germination response to temperature, dormancy loss, and priming effects in Elymus elymoides. Seed Sci. Res. 10(3): 213-223. doi: 10.1017/S0960258500000246. 
Michel, B.E. 1983. Evaluation of the water potentials of solutions of polyethylene glycol 8000 both in the absence and presence of other solutes. Plant Physiol. 72(1): 66-70.

Momoh, E.J.J., Zhou, W.J., and Kristiansson, B. 2002. Variation in the development of secondary dormancy in oilseed rape genotypes under conditions of stress. Weed Res. 42(6): 446-455. doi: 10.1046/j.1365-3180.

Murdoch, A.J. 2006. Soil seed banks. In: Handbook of seed science and technology (ed Basra AS). Food Products Press, New York, pp.501-519.

Roberts, H.A., and Boddrell, J.E. 1983. Seed survival and periodicity of seedling emergence in eight species of Cruciferae. Ann. App. Biol. 103(2): 301-309. doi: 10.1111/j.1744-7348.1983.tb02768.x

Roberts, H.A., and Dawkins, P.A. (1967) Effect of cultivation on the numbers of viable weed seeds in soil. Weed Res. 7(4): 290-301. doi: 10.1111/j.1365-3180.

Roberts, H.A., and Feast, P.M. 1973a. Changes in the numbers of viable weed seeds in soil under different regimes. Weed Res. 13(3): 298-303. doi: 10.1111/j.13653180.

Roberts, H.A., and Feast, P.M. 1973b. Emergence and longevity of seeds of annual weeds in cultivated and undisturbed soil. J. Appl. Eco. 10(1): 133-143. doi: $10.2307 / 2404721$

Samimy, C., and Khan, A.A. 1983. Secondary dormancy, growth-regulator effects, and embryo growth potential in curly dock (Rumex crispus) seeds. Weed Sci. 31: $153-158$.

Soltani, A., Roberson, M.J., Torabi, B., Yousefi-Daz, M., and Sarparast, R. 2006. Modeling seedling emergence in chickpea as influenced by temperature and 
sowing depth. Agric. For. Meteor. 138(1-4): 156-167. doi:

10.1016/j.agrformet.2006.04.004

Soltani, A., Zeinali, E., Galeshi, S., and Latifi, N. 2001. Genetic variation for and interrelationships among seed vigor traits in wheat from the Caspian Sea coast of Iran. Seed Sci. Technol. 29(4): 653-662.

Soltani, E., Soltani, A., Galeshi, S., Ghaderi-Far, F., and Zeinali, E. 2013. Seed bank modelling of volunteer oil seed rape: from seeds fate in the soil to seedling emergence. Planta Danin. 31(2): 267-279. doi: 10.1590/S0100-

83582013000200004.

Steckel, L. E., Sprague, C. L., Stoller, E. W., Wax, L. M. and Simmons, F. W. 2007. Tillage, cropping system, and soil depth effects on common waterhemp (Amaranthus rudis) seed-bank persistence. Weed Sci. 55(3), 235-239. doi: http://dx.doi.org/10.1614/WS-06-198

Taab, A., and Andersson, L. 2009. Seasonal changes in seed dormancy of Solanum nigrum and Solanum physalifolium. Weed Res. 49(1): 90-97. doi: 10.1111/j.1365-3180.2008.00674.x.

Walck, J.L., Baskin, J.M., Baskin, C.C., and Hidayati, S.N. 2005. Defining transient and persistent seed banks in species with pronounced seasonal dormancy and germination patterns. Seed Sci. Res. 15(3): 189-196. doi: 10.1079/SSR2005209.

Walker, S., Wu, H. and Bell, K. (2010). Emergence and seed persistence of Echinochloa colona, Urochloa panicoides and Hibiscus trionum in the subtropical environment of north-eastern Australia. Plant Prot. Quart. 25(3), 127132. 
Table 1 - Parameter estimates of the thermal time model describing nondormant seed germination of $S$. arvensis at a range of water potentials. Prior to the test, seeds were treated with $\mathrm{GA}_{3}$ to release primary dormancy. At each water potential, seeds were incubated at 5, 10, 15, 20, 25, 30 and $35{ }^{\circ} \mathrm{C} . \mathrm{T}_{\mathrm{b}}, \mathrm{T}_{\mathrm{o} 1}, \mathrm{~T}_{\mathrm{o} 2}$ and $\mathrm{T}_{\mathrm{c}}$, base, lower optimum, upper optimum and ceiling temperatures $\left({ }^{\circ} \mathrm{C}\right)$, respectively; $\mathrm{R}_{\max }$, maximum rate of germination $\left(\mathrm{h}^{-1}\right)$; Final (\%), mean germination percentage at each water potential; $\mathrm{R}^{2}$ coefficient of determination of the regression thermal time model; and $\mathrm{TT}_{(50)},{ }^{\circ} \mathrm{C}$ day thermal time for $50 \%$ of maximum germination at sub- and supra-optimal temperatures. Numbers in parentheses represent the standard errors.

\begin{tabular}{|c|c|c|c|c|c|c|c|c|c|c|c|}
\hline \multirow{2}{*}{$\begin{array}{c}\text { WP } \\
(\mathrm{MPa})\end{array}$} & \multirow{2}{*}{$\mathrm{T}_{\mathrm{b}}$} & \multirow{2}{*}{$\mathrm{T}_{\mathrm{o} 1}$} & \multirow{2}{*}{$\mathrm{T}_{\mathrm{o} 2}$} & \multirow{2}{*}{$\mathrm{T}_{\mathrm{c}}$} & \multirow{2}{*}{$\mathrm{R}_{\max }$} & \multicolumn{3}{|c|}{ Sub-optimal } & \multicolumn{3}{|c|}{ Supra-optimal } \\
\hline & & & & & & Final (\%) & $\mathrm{TT}_{(50)}$ & $\mathrm{R}^{2}$ & Final (\%) & $\mathrm{TT}_{(50)}$ & $\mathrm{R}^{2}$ \\
\hline 0 & $1.94(0.456)$ & $21.35(3.022)$ & $22.55(2.776)$ & $36.46(2.500)$ & $0.0160(0.0002)$ & $83.1(1.28)$ & $50.54(1.768)$ & 0.98 & $24.7(3.05)$ & $35.82(3.816)$ & 0.93 \\
\hline-0.2 & $1.87(0.376)$ & $21.18(2.904)$ & $21.66(3.187)$ & $36.57(2.655)$ & $0.0149(0.0002)$ & $60.0(1.86)$ & $54.04(1.868)$ & 0.98 & $16.7(3.89)$ & 41.07 (4.567) & 0.92 \\
\hline-0.4 & $0.67(0.345)$ & $17.24(0.787)$ & $24.75(0.235)$ & $30.00(0.162)$ & $0.0106(0.0003)$ & $43.3(1.88)$ & 70.64 (1.667) & 0.99 & $9.3(2.11)$ & $20.65(4.406)$ & 0.95 \\
\hline-0.6 & $0.30(0.554)$ & $18.57(1.127)$ & $25.00(4.199)$ & $29.99(2.159)$ & $0.0102(0.0003)$ & $28.6(1.69)$ & $79.30(2.213)$ & 0.99 & $7.3(2.75)$ & $19.66(1.599)$ & 0.95 \\
\hline
\end{tabular}


Table 2 - Parameter estimates of the hydrotime model for seven temperatures describing nondormant seed germination of S. arvensis at a range of water potentials. Prior to the test, seeds were treated with $\mathrm{GA}_{3}$ to release primary dormancy. $\psi_{\mathrm{b}(50)}$, median base water potential; $\sigma_{\psi b}$ standard deviation of base water potential; $\mathrm{HT}_{(50)}$, hydrotime constant (MPa-hours); $\mathrm{R}^{2}$, coefficient of determination of the regression hydrotime model; and Final (\%), mean germination percentage (numbers in parentheses represent the standard errors) at each temperature.

\begin{tabular}{rrrrrr}
\hline $\begin{array}{c}\text { Temperature } \\
\left({ }^{\circ} \mathrm{C}\right)\end{array}$ & $\psi_{\mathrm{b}(50)}$ & $\sigma_{\psi \mathrm{b}}$ & $\mathrm{HT}_{(50)}$ & $\mathrm{R}^{2}$ & Final (\%) \\
\hline 5 & -0.544 & 0.337 & 159.05 & 0.92 & $50.88(3.54)$ \\
10 & -0.681 & 0.596 & 131.53 & 0.98 & $56.88(2.62)$ \\
15 & -0.737 & 0.607 & 90.22 & 0.97 & $56.53(2.87)$ \\
20 & -0.463 & 0.334 & 31.87 & 0.92 & $50.28(3.45)$ \\
25 & -0.096 & 0.622 & 39.19 & 0.96 & $32.63(2.16)$ \\
30 & 0.064 & 0.366 & 34.59 & 0.94 & $9.00(1.42)$ \\
\hline
\end{tabular}


Figure captions:

Fig 1. Changes in (a) germinability of Sinapis arevensis seeds buried on 23 Sept. 2009, and (b) maximum and minimum soil temperatures. Air temperatures obtained from a weather station in Gorgan were converted to soil temperatures using equation 1. Error bars are $\pm 1 \mathrm{SE}$. MF, maintained in field; ML, maintained in lab.

Fig 2. Effect of temperature and water potential on germination rate (hour ${ }^{-1}$ ) of Sinapis arevensis seeds. The lines show dent-like functions used to describe the response of germination rate to temperature at each of the four water potentials. Error bars are $\pm 1 \mathrm{SE}$.

Fig 3. Germination time courses for seeds of Sinapis arvensis incubated at each of four water potentials at $5,10,15,20,25$ and $30^{\circ} \mathrm{C}$. Symbols indicate interpolations of observed germination data and lines germination time courses predicted by the hydrotime model based on parameter estimates in Table 2.

Error bars are $\pm 1 \mathrm{SE}$.

Fig 4. Effects of temperature and water potential on dormancy induction in Sinapis arvensis seeds. The lines show segmented functions used to describe the response of dormancy induction to temperature for each water potential.

Error bars are $\pm 1 \mathrm{SE}$.

Fig 5. Changes in the parameters of the model used to explain dormancy induction. (a) Minimum dormancy, Dmin, and (b) threshold temperature for dormancy induction (TTDI). Lines are fitted linear regressions that describe changes in parameters in response to water potential.

Error bars are $\pm 1 \mathrm{SE}$.

Fig 6. Fates of Sinapis arvensis seeds at the different soil depths in a pot experiment. 
Fig 7. Relationship between seedling emergence percentage (a) and emergence rate (b) with burial depth in Sinapis arvensis seeds. Error bars are $\pm 1 \mathrm{SE}$.

Fig 8. Relationship between dormant seeds (\%) and burial depth in Sinapis arvensis. The line shows segmented function used to describe the response of dormancy induction to burial depth.

Error bars are $\pm 1 \mathrm{SE}$. 

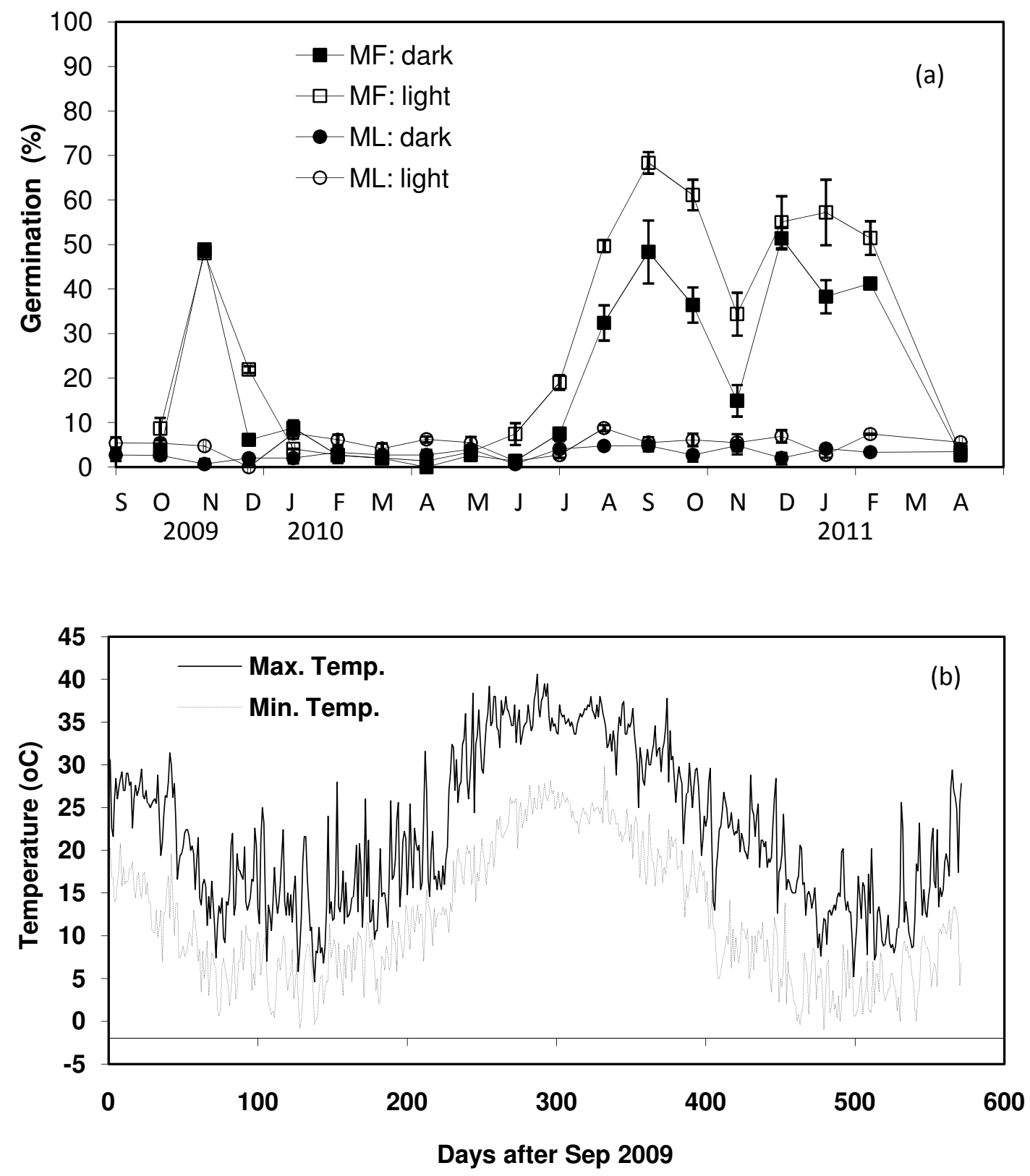

Figure1. xxx 


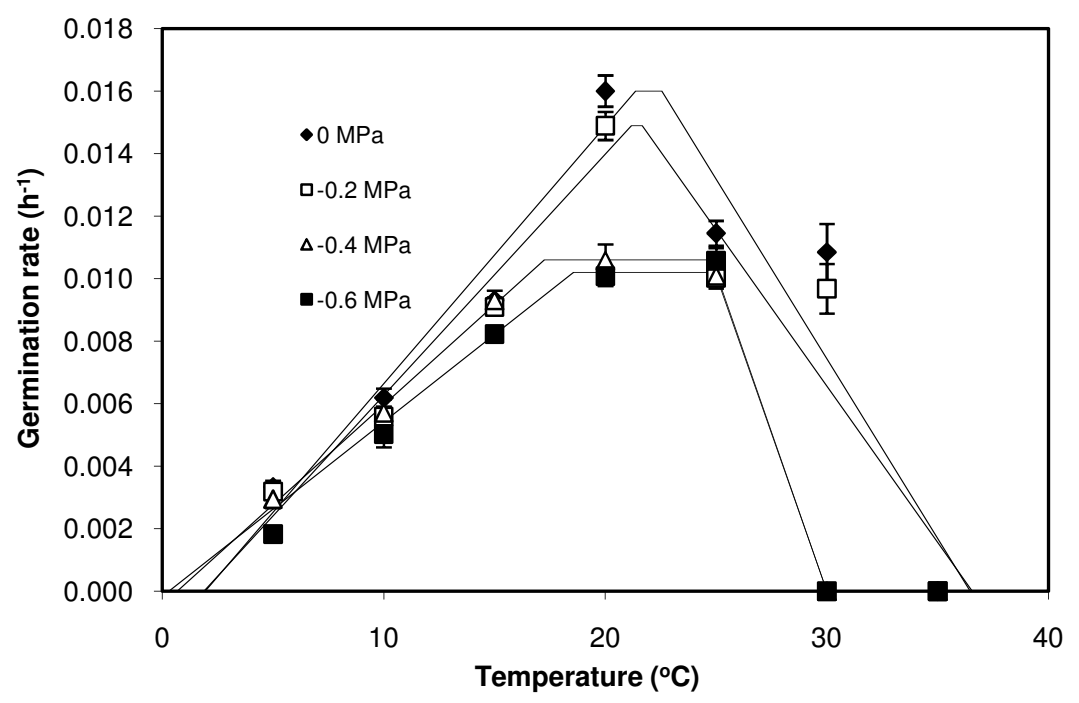

Figure2. $x x x$ 

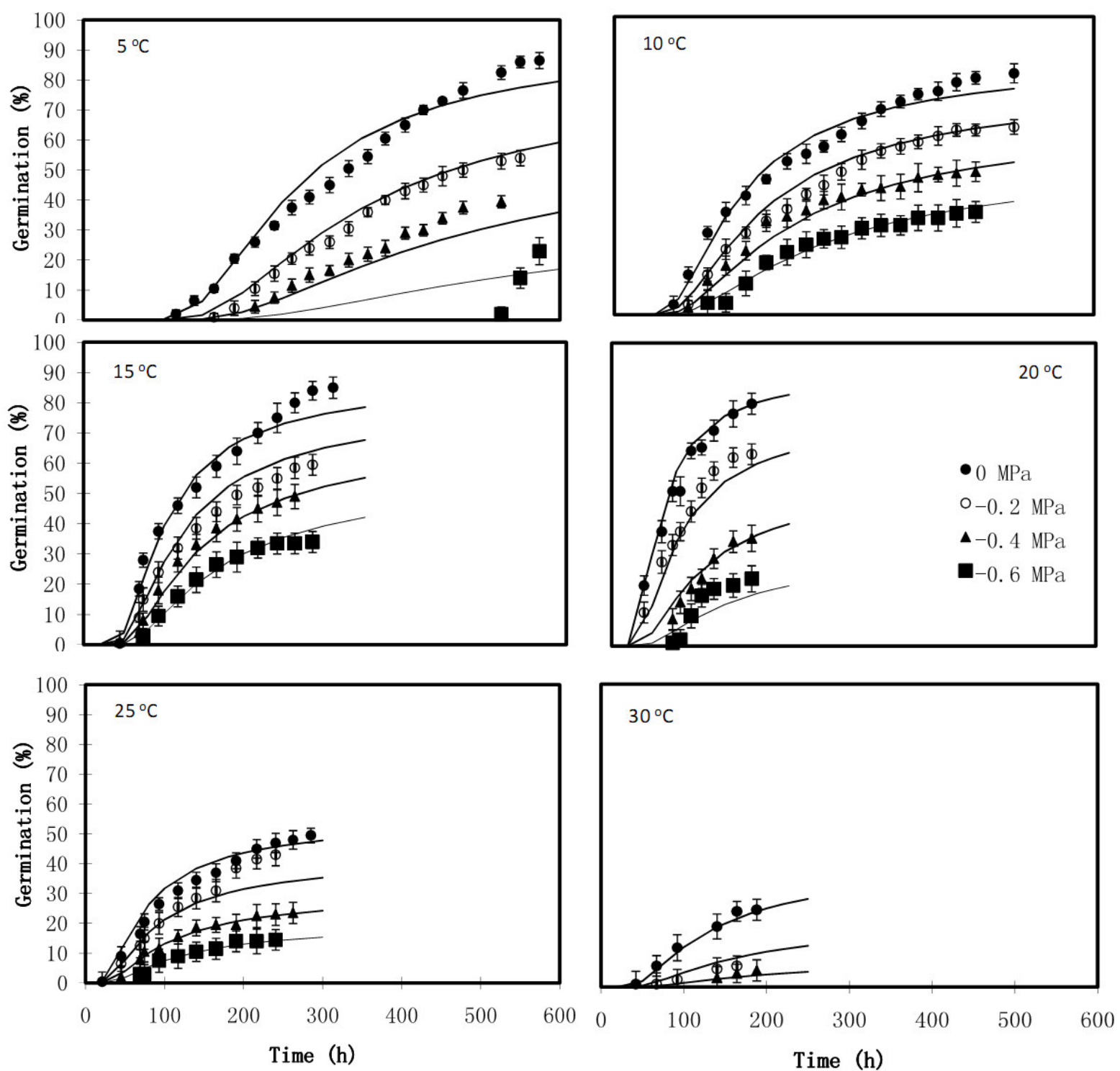

Figure3. xxx 


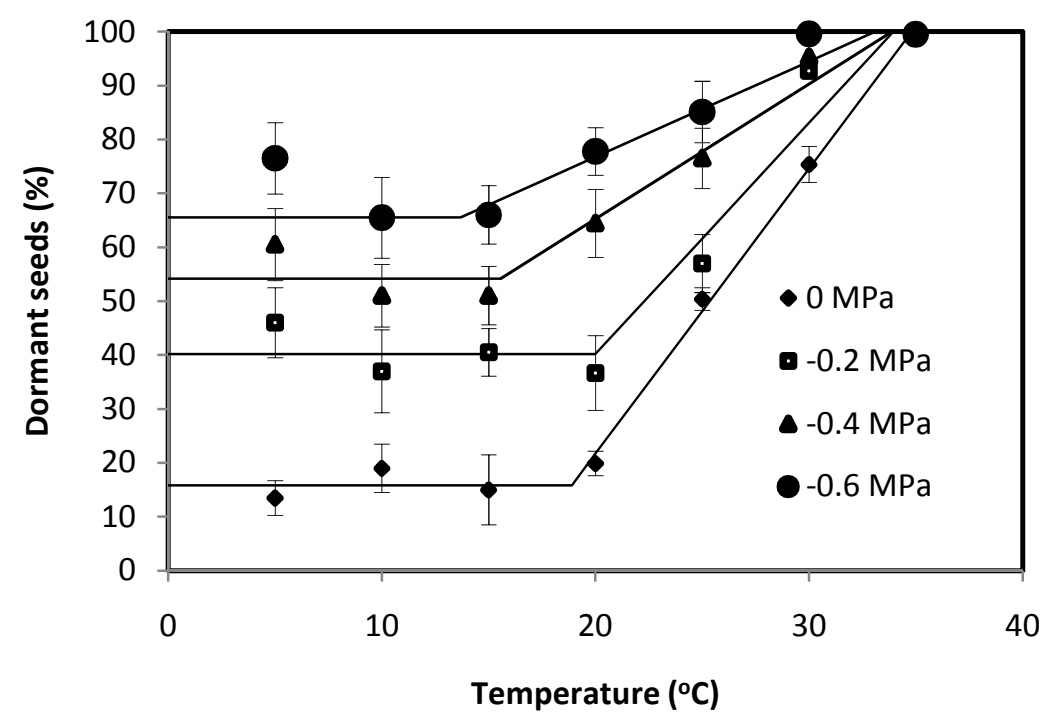

Figure4. xxx 

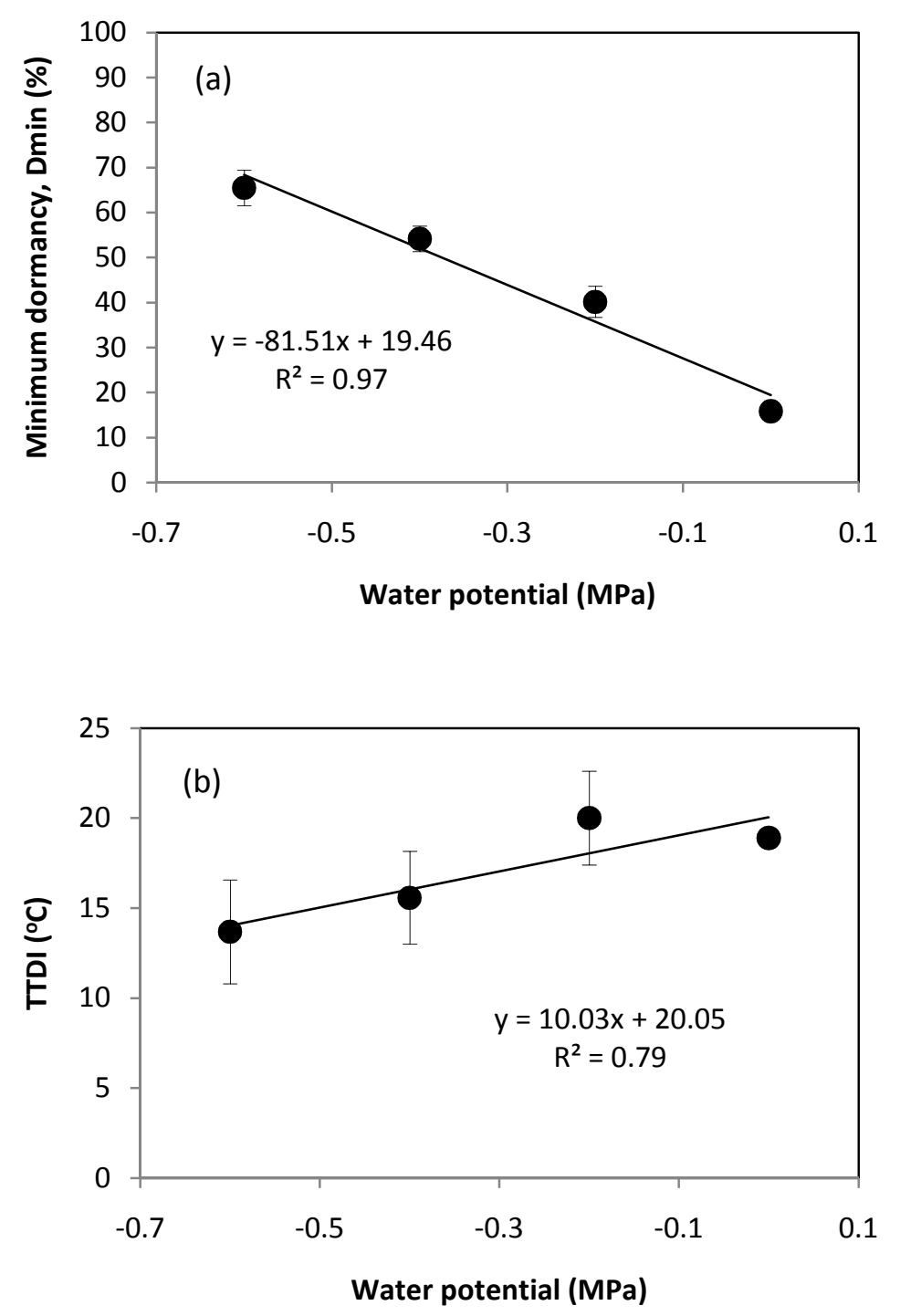

Figure5. $x x x$ 


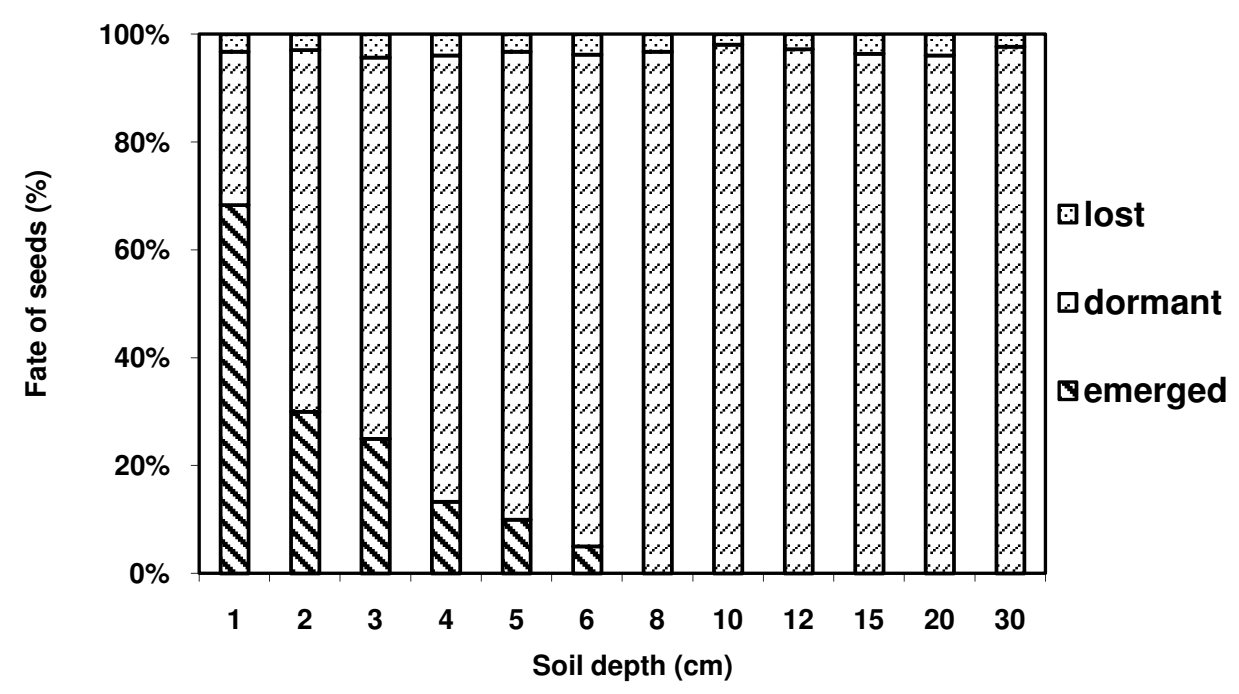

Figure6. xxx 

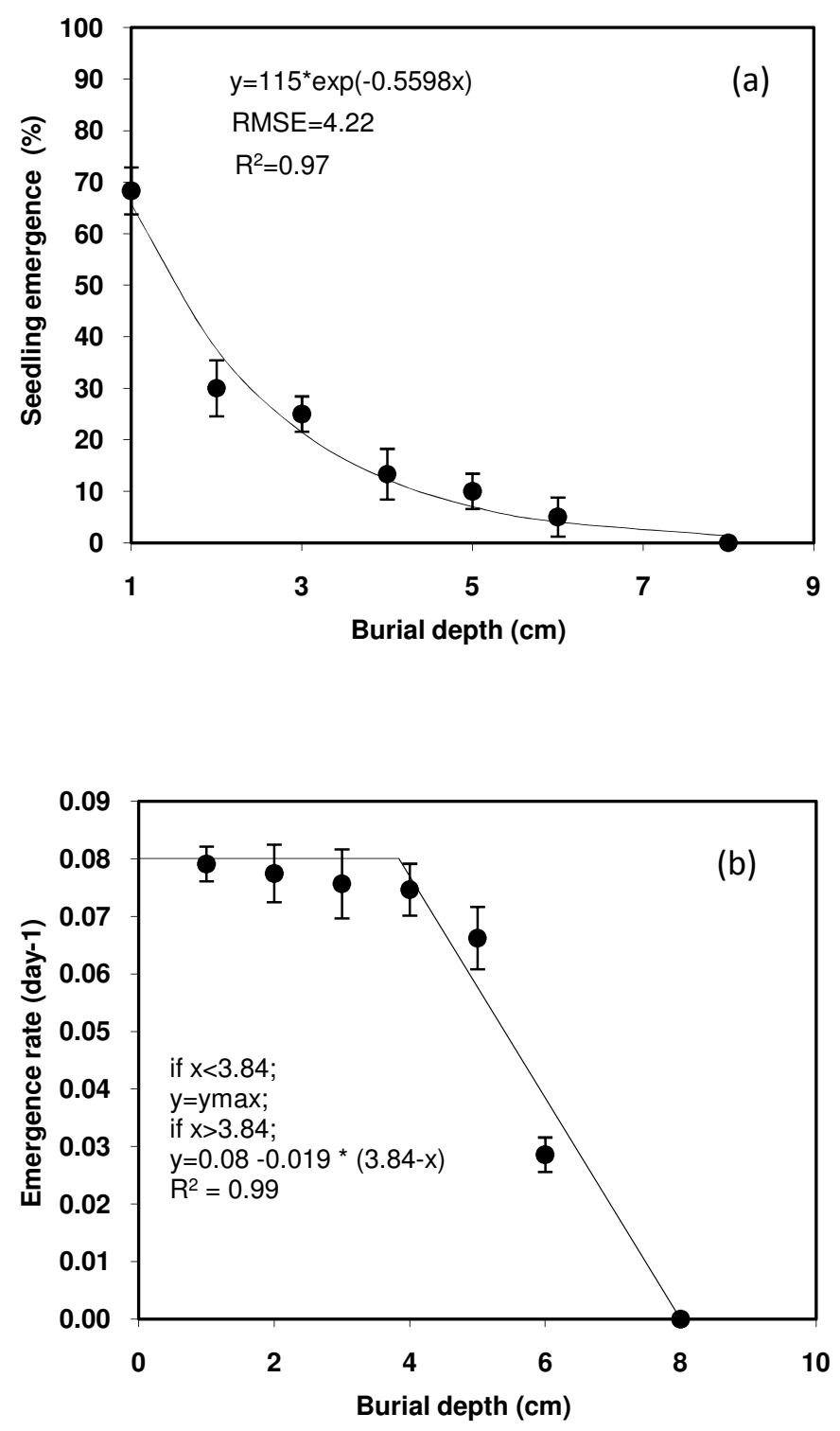

Figure7. $\mathrm{xxx}$ 


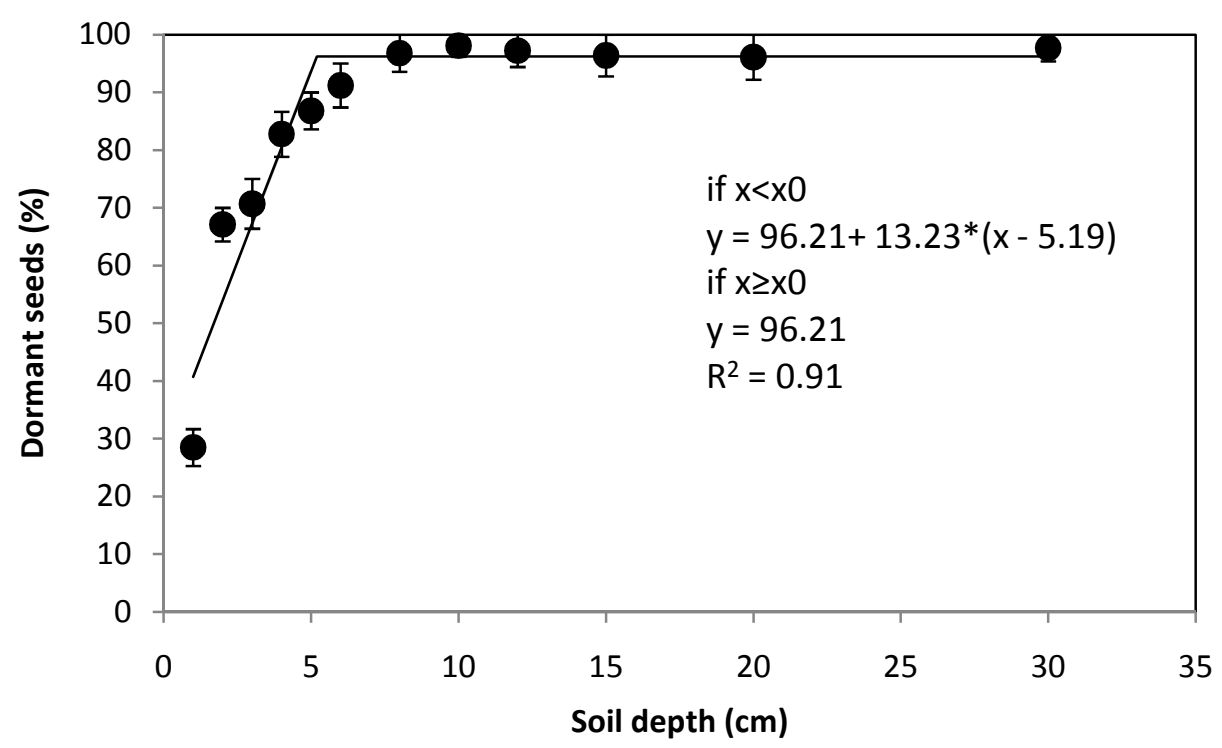

Figure8. xxx 